\title{
DROPSHIPPING PADA CV. KARYA UTAMA SURABAYA TERHADAP PEMBERDAYAAN KAFFAHISME EKONOMI PERSPEKTIF HUKUM ISLAM
}

\author{
Syarifuddin Hidayatullah Hamdani \\ Surabaya \\ alfanzaarif@gmail.com
}

\begin{abstract}
This study examines the dropshipping activities carried out by CV. Karya Utama Surabaya in empowering economic kaffahism. This study uses a descriptive method with a qualitative approach. The collected data were analyzed using descriptive qualitative analysis method. The purpose of this study was to determine the implementation of dropshipping activities in empowering economic kaffahism and dropshipping practices with an Islamic perspective. The result of this research is the implementation of dropshipping has contributed to economic empowerment evenly. Dropship is allowed in Islam as long as there is no argument for prohibiting it by using the contract and its respective consequences such as the salam contract, wakalah and samsarah. The author suggests internet-based business and marketing players, in this case CV. Karya Utama Surabaya (supplier) and modern sales force (dropshipper). Among them, dropshippers are required to be able to provide the totality of services to anyone who is involved in the world of online buying and selling and marketing based on modern technology. Meanwhile, CV. Karya Utama Surabaya as a supplier must also be selective in choosing dropshippers who want to partner with the company.
\end{abstract}

Keywords: Dropship, Empowerment, Kaffahism of Economy

\begin{abstract}
Abstrak: Penelitian ini meneliti tentang kegiatan dropshipping yang dilaksanakan oleh CV.Karya Utama Surabaya dalam pemberdayaan kaffahisme ekonomi. Penelitian ini menggunakan metode deskriptif dengan pendekatan kualitatif. Data yang terkumpul dianalisis dengan menggunakan metode analisis deskripstif kualitatif. Tujuan penelitian ini untuk mengetahui implementasi kegiatan dropshipping dalam pemberdayaan kaffahisme ekonomi dan praktik dropship perspektif Islam. Hasil dari penelitian ini ialah implementasi dropship memberikan sumbangsih pemberdayaan ekonomi secara merata. Dropship diperbolehkan di dalam Islam selama tidak ada dalil atas pelarangannya dengan menggunakan akad serta konsekuensi masingmasing seperti akad salam, wakalah dan samsarah. Penulis menyarankan terhadap pelaku bisnis dan pemasaran berbasis internet yang dalam hal ini adalah CV. Karya Utama Surabaya (suplier) dan tenaga pemasar modern (dropshipper). Di antaranya dropshipper dituntut mampu memberikan totalitas pelayanan kepada siapa saja yang berkecimpung dalam dunia jual beli online dan pemasaran berbasis teknologi modern. Sedangkan CV. Karya Utama Surabaya sebagai supplier juga harus selektif memilih dropshipper yang hendak bermitra dengan perusahaan.
\end{abstract}

Kata Kunci: Dropship, Pemberdayaan, Kaffahisme Ekonomi.

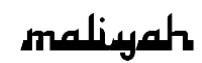

Jurnal Hukum Bisnis Islam

Volume 10, Nomor 01, Juni 2020

p-ISSN: 2088-4869/ e-ISSN: 2597-4351 


\section{Pendahuluan}

Era milenial ini manusia dimudahkan dalam segala aspek perekonomian dan perilaku yang modern. Beberapa di antaranya adalah eksistensi dunia maya dan bebasnya berselancar internet di manapun serta oleh siapapun yang mumpuni. Kemudian dari sana, muncul setidaknya tindakan atau perilaku manusia untuk mengembangkan dalam dunia yang lebih prospek dan berorientasi bisnis (business oriented atau money oriented). Kegiatan jual-beli di zaman modern saat ini telah dibagi menjadi dua macam, jual-beli sistem offline dan online. Seperti banyak diketahui, jual-beli sistem offline sudah marak dijalankan sebelum zaman Rasulullah Saw hingga era globalisasi. Sedangkan jual-beli sistem online merupakan terobosan baru dan dijumpai banyak kemudahan-kemudahan di dalamnya.

Jual-beli sistem online berbeda dengan sistem offline, yang mana sistem online tersebut tidak mengharuskan seorang penjual dan pembeli berkumpul dalam satu majelis (lapak). ${ }^{1}$ Bisnis modern (online) dapat memunculkan generasi seller dan buyer yang kritis serta cerdas dikarenakan penjual dapat dengan mudah menawarkan barangnya tidak pada satu majelis (lapak) saja dengan memberikan deskripsi barang yang sesuai dan apa adanya. Sedangkan seorang pembeli dapat dengan cermat membandingkan (compare) produk atau jasa tanpa harus berpindah dari satu tempat ke tempat yang lain. ${ }^{2} \mathrm{Hal}$ ini merupakan implementasi keefesiensian serta kefektifan waktu seller dan buyer dalam melaksanakan kegiatan ekonominya.

Salah satu bentuk eksistensi yang tengah berkembang pesat terkait disruptif teknologi ialah kegiatan ekonomibisnis yang melibatkan orang lain (perantara) di dalam

\footnotetext{
${ }^{1}$ Unggul Pambudi Putra, Sukses Jual Beli Online (Jakarta: Elex Media Komputindo, 2014). 18

${ }^{2}$ Ika Yunia Fauzia, “Akad Wakalah Dan Samsarah Sebagai Solusi Atas Klaim Keharaman Dropship Dalam Jual Beli Online,” Jurnal Islamica Vol. 9, No (n.d.): 323-343.
} 
aktivitas jual beli. Secara praktis, setiap perantara modern ini melaksanakan kegiatan jual beli dengan melakukan motode pemasaran online. Di samping itu ada juga imbalan yang kemudian didapatkan setelah melaksanakan kegiatan (sebagai perantara) dengan baik dan menghasilkan. Kegiatan semacam ini di dalam dunia modern lebih dikenal dengan sebutan dropship.

Kegiatan dropship yang jamak dilakukan dewasa ini, dapat menimbulkan tanda tanya besar. Pasalnya, dropshipper hanya menggunakan gambar saja untuk menjual barang meskipun dengan berbagai media yang dimiliki. Sedangkan menurut beberapa ahli fikih, berpendapat bahwa dalam aktivitas jual-beli (khususnya seller) harus mengetahui barang yang dijualnya (mulai dari bentuk, warna, deskripsi detail dan lain sebagainya) secara langsung untuk menghindari hal-hal yang tidak diinginkan.

Salah satu contoh bisnis yang membutuhkan mitra atau perantara dalam penjualan barangnya adalah CV. Karya Utama Surabaya. ${ }^{3}$ CV. Karya Utama Surabaya merupakan salah satu penerbit dan percetakan berskala nasional yang ada di Surabaya, terdiri dari banyak varian buku yang diterbitkan serta dicetak yang kemudian dipasarkan secara masif ke seluruh wilayah Indonesia. Untuk melakukan ekspansi pasar yang statis dan masif, maka dari itu CV. Karya Utama Surabaya yang dalam hal ini sebagai suplier buku (penerbit dan percetakan) memberikan kesempatan kepada siapapun untuk menjadi mitra baik sebagai reseller ataupun dropshipper.

Pentingnya kerja sama dan saling tolong menolong dalam kebaikan juga dapat mempelopori lahirnya kaffahisme (ke-kaffah-an) berekonomi. Kaffahisme ekonomi merupakan sistem ekonomi yang melibatkan partisipasi umat, membawa dampak positif terhadap lingkungannya serta menyadarkan

\footnotetext{
${ }^{3}$ Perusahaan skala nasional yang bergerak di bidang percetakan, Penerbitan Dan Distiburi Buku. Berada Di Jl. Kasuari Blok A-012 No. 15 Krembangan Surabaya (60175), n.d.
} 
keuntungan di dunia berasal dari besar kecilnya rezeki yang diturunkan Allah Swt kepada umat. Tujuan dari penelitian ini adalah untuk mengetahui bagaimana implementasi kegiatan dropshipping dalam pemberdayaan kaffahisme ekonomi oleh CV. Karya Utama Surabaya dan untuk mengetahui bagaimana implementasi dropship dalam perspektif Islam.

Penelitian ini merupakan penelitian kualitatif, yang dilakukan pada kondisi objek yang alami, peneliti sebagai instrumen kunci, teknik pengumpulan data dilakukan secara gabungan, data yang dihasilkan bersifat deskriptif dan analisis data dilakukan secara induktif serta penelitian ini lebih menekankan makna daripada generalisasi. ${ }^{4}$ Dalam penelitian ini, peneliti melakukan pengamatan terhadap aktivitas atau kegiatan dropship dalam jual beli online, dropship perspektif Islam, ekspansi bisnis dan pemberdayaan kaffahisme ekonomi. Data diperoleh dengan cara wawancara, dokumentasi, dan studi kepustakaan. Setelah berbagai data terkumpul, maka untuk menganalisis digunakan teknik deskriptif komparatif. Penelitian ini bersifat membandingkan. Penelitian ini dilakukan untuk membandingkan perbedaan dua atau lebih fakta-fakta dan sifat-sifat objek yang diteliti berdasarkan kerangka pemikiran tertentu. Pada penelitian ini variabelnya masih mandiri, tetapi untuk sampel yang lebih dari satu dalam waktu yang berbeda. ${ }^{5}$ Teknik deskriptif komparatif digunakan untuk memaparkan mekanisme operasional akad samsarah dalam meng-cover kegiatan dropship CV. Karya Utama Surabaya, kemudian menganalisis tentang mekanisme, tantangan dan peluang dalam kegiatan jual beli online yang dilakukan para dropship di CV. Karya Utama Surabaya terhadap pemberdayaan kaffahisme ekonomi.

\section{Definisi Dropship}

\footnotetext{
${ }^{4}$ Syarifudin. Sedarmayanti, Metodologi Penelitian(Bandung: Mandar Maju, 2002).33

${ }^{5}$ Lexy J Moleong, Metode Penelitian Kualitatif(Bandung: Remaja Rosdakarya, 1994). 105
} 
Secara umum, di dalam Kamus Besar Bahasa Indonesia menjelaskan dua pengertian tentang dropship. Pertama, adalah perantara Perantara perdagangan antara pembeli dan penjual atau orang yang menjualkan barang atau orang yang mencarikan pembeli. Kedua, Orang atau badan hukum yang berjual beli sekuritas atau barang untuk orang lain atas dasar komisi. ${ }^{6}$

Dropship menurut Zuhdi, merupakan kata yang berasal dari bahasa Arab yakni "Samsarah" yang memiliki definisi perantara perdagangan antara penjual dan pembeli untuk sebuah kemudahan di dalam aktivitas jual-beli. ${ }^{7}$ Sedangkan menurut Mujtaba, Dropship merupakan pedagang perantara yang bertugas menjualkan barang orang lain dengan mengambil upah atau mencari keuntungan sendiri tanpa menanggung risiko. ${ }^{8}$

Segala sesuatu yang dilandaskan pada asas islami akan menuai kebaikan di masa yang akan datang. Aktivitas dropship misalnya, terdapat unsur dan mengandung nilai-nilai kebajikan yang di dalamnya tidak menentang syariah agama. Antara lain unsur tolong-menolong, hal ini sesuai dengan Firman Allah dalam Surat Al-Maidah Ayat 2 yang artinya : "Dan tolongmenolonglah kamu dalam (mengerjakan) kebajikan dan takwa, dan jangan tolong-menolonglah dalam berbuat dosa serta pelanggaran. Dan bertakwalah kamu kepada Allah, sesungguhnya Allah amat berat siksa-Nya."(Al-Maidah:2)

Selanjutnya dropship juga mengandung unsur kemaslahatan. Seperti halnya saluran distribusi yang semakin pendek, menambah jaringan relasi dan ekspansi bisnis, mendapatkan tenaga pemasar yang mumpuni serta biaya operasional tidak membengkak, konsumen dapat menentukan kebutuhan yang akan diperoleh melalui beberapa pilihan

\footnotetext{
${ }^{6}$ Tim Prima Pena, Kamus Besar Bahasa Indonesia, n.d.126

${ }^{7}$ Masjfuk Zuhdi, Masailul Fiqhiyah (Jakarta: Haji Masagung, 1993).121

${ }^{8}$ Saifuddin Mujtaba, Masailul Fiqhiyah (Jombang: Rousyan Fiqr, 2007).239
} 
penyedia barang (dropshipper) karena keberadaannya yang tidak sulit ditemukan.

Dalam hal ini, Yusuf Qardhawi menjelaskan bahwasanya siapa saja dapat menjadi makelar, simsar, perantara, dropshipper dan lain sebagainya baik orang yang ada dalam satu majelis atau majelis yang berbeda sekalipun. Di dalam aktivitas semacam ini terdapat sebuah kemudahan yang gamblang seperti memudahkan keluar masuknya barang dari daerah satu ke daerah yang lainnya atas bantuan simsar atau dropshipper, dengan demikian akan ada keuntungan dari kedua belah pihak. $^{9}$

Unsur kemudahan yang lainnya ada pada pihak dropshipper yang tidak harus memiliki barang terlebih dahulu. Hal ini cukup meringankan karena dropship merupakan jawaban atas keberlangsungan bisnis dengan minimnya modal yang dimiliki. Dery Iswidharmanjaya menambahkan, dropshipping merupakan suatu usaha penjualan produk tanpa harus memiliki produk apapun. ${ }^{10}$

Dalam kaidah fikih, kegiatan dropship semacam ini ditangguhkan pada beberapa akad, antara lain salam, wakalah dan samsarah. Pertama, secara terminologis akad salam ialah menjualkan barang dengan spesifikasi jelas dan akurat tetapi penyerahan tertunda (pembayaran dilakukan terlebih dahulu dan barang diserahkan di kemudian hari).11 Menurut Kompilasi Hukum Ekonomi Syariah (KHES), salam merupakan jasa pembiayaan yang berkaitan dengan jual beli dan pembiayaannya dilakukan bersamaan dengan pemesanan barang. ${ }^{12}$

\footnotetext{
${ }^{9}$ Y usuf Qadhawi, Halal Dan Haram Dalam Islam (Terjemah Mu'alam Hamidy) (Surabaya: Bina Ilmu, 1993).46

${ }^{10}$ Dery Iswidharmanjaya, Dropshipping Cara Mudah Bisnis Online (Jakarta: PT. Elex Media Komputindo, 2012).5

${ }^{11}$ M Ali Hasan, Berbagai Macam Transaksi Dalam Islam (Fiqh Muamalat) Ed. 1 Cet. 2 (Jakarta: PT Raja Grafindo Persada, 2004).143

12 Tim Fokusmedia, Kompilasi Hukum Ekonomi Syariah, Edisi 2011 (Bandung: Fokusmedia, 2011).
} 
Secara lebih spesifik, salam didefinisikan sebagai bentuk jual beli dengan pembayaran di awal dan penyerahan barang di kemudian hari dengan harga, spesifikasi, jumlah, kualitas, tanggal dan tempat penyerahan yang jelas serta disepakati sebelumnya dalam sebuah perjanjian. ${ }^{13}$ Konsekuensi yang didapat ialah dropshipper harus menjelaskan dengan detail atas barang yang akan dijualnya.

Kedua, akad wakalah secara bahasa bermakna menyerahkan dan mempercayakan. Wakalah atau wikalah juga berarti tafwidh (penyerahan, pendelegasian, pemberian mandat). ${ }^{14}$ Konsekuensi yang berlaku adalah dropshipper tidak diperkenankan mengambil keuntungan di luar jual beli yang dilakukan. Artinya, keuntungan sudah ditetapkan pada perjanjian awal dengan pemilik barang.

Ketiga, samsarah secara bahasa adalah perantara di antara penjual dan pembeli untuk menyempurnakan jual beli. Secara istilah, samsarah merupakan perantara perdagangan baik sebagai orang yang menjualkan barang maupun mencarikan pembeli, atau perantara antara penjual dan pembeli untuk memudahkan jual beli. ${ }^{15}$ Konsekuansinya adalah dropshipper harus menjalin hubungan kerja sama baik secara lisan atau perjanjian tertulis mengenai kesepakatan, harga jual, spesifikasi produk dan keuntungan. Fungsi dropshipper di sini hanya sebagai pemasar (marketer) dan berhak mendapatkan ujrah atau upah (fee) dari setiap barang yang berhasil terjual. Transaksi semacam ini di dalam fikih muamalah disebut dengan transaksi jualah yang artinya suatu janji upah apabila dropshipper mampu menyelesaikan pekerjaannya dengan baik.

\section{Etika Dropship Dalam Pemasaran Syariah}

\footnotetext{
${ }^{13}$ Ascarya, Akad Dan Produk Bank Syariah (Jakarta: RajaGrafindo Persada, 2011). 90

${ }^{14}$ Abdul Rahman Ghazali, Fiqh Muamalat (Jakarta: Kencana, 2010).189

${ }^{15}$ Hasan, Berbagai Macam Transaksi Dalam Islam (Fiqh Muamalat) Ed. 1 Cet. 2.289
} 
Aktivitas pemasaran modern di zaman disruptif teknologi ini harus tetap menelaah dan menjalankan sesuai konsep yang berlaku. Dropship merupakan kegiatan aktif dalam dunia maya yang kemudian bernilai produktif serta menghasilkan feedback positif tanpa meninggalkan etika dalam implementasinya.

Prinsip etika pemasaran didasarkan pada sebuah konsep nilai kebaikan, kemaslahatan dan keadilan. Miskawayh berpendapat bahwasanya keadilan mengajarkan seseorang untuk tidak menjadi tamak di dalam mendapatkan keuntungan yang sah menurut hukum. ${ }^{16}$

Miskawayh kemudian mengatakan juga bahwa seorang pelaku bisnis yang jujur dan adil hendaknya menaati aturan Allah tentang janjinya dan akad perjanjian pada setiap ucapan kata-katanya serta tiap kedipan matanya. Seseorang pelaku bisnis tidak harus dari kelompok orang adil jika dia memiliki kecintaan uang yang berlebihan, karena hasrat memperoleh uang mencegah seseorang bersikap baik, melihat apa yang benar dan memberi apa yang ia perlu berikan.

Nasuka mengutip pendapat Miskawayh yang berpendapat jika dorongan praktik pemasaran yang tidak pantas sebagai maksimalisasi keuntungan digeser ke arah maksimalisasi nilai kejujuran sebagai gantinya, dan jika keadilan menjadi hal yang tidak bisa dipisahkan dari bagian interaksi-interaksi pemasaran internasional dan saling ketergantungan, suatu suasanakerjasama global yang harmonis akan tercipta. ${ }^{17}$

Sedangkan Saeed menyatakan bahwa etika pemasaran Islam didasarkan pada prinsipkeadilan dan kejujuran. ${ }^{18}$ Dalam Islam berbeda dengan etika sekuler dalam banyak hal.

\footnotetext{
${ }^{16}$ Miskawayh dalam Nasuka, "Etika Pemasaran Berbasis Islam," Mukaddimah No.17 No.1 (2011): 92.

${ }^{17}$ Ibid.92

${ }^{18}$ Mohammad Saeed Dll, "International Marketing Ethics an Islamic Perspective," Journal of Bisnis Ethics Vol.32 No. (2001): 127-142.
} 
Terdapat tiga karakteristik etika pemasaran dari perspektif Islam. Pertama, etika Islam didasarkan pada perintah-perintah Al-Quran dan tidak meninggalkan ruang untuk perbedaan interpretasi oleh pelaku pemasaran sesuai dengan kehendak dan keinginan masing-masing. Kedua, perbedaan utama adalah aspek trensendental mereka secara mutlak dan watak aslinya yang tidak mudah dipengaruhi. Ketiga, pendekatan Islam menekankan pada memaksimalkan nilai yang mementingkan kebaikan masyarakat dari pada mengejar keuntungan pribadi sebanyak mungkin. Sikap seperti itu, menjamin etika Islam memiliki kapasitas yang sangat besar untuk menembus hati nurani manusia dan mampu mempengaruhi perilaku para pelakupemasaran dari dalam. ${ }^{19}$

\section{Pemasaran Dropshipping Berlandaskan Marketing Sharia}

Pemasaran adalah suatu proses sosial dan manajerial yang di dalamnya ada individu dan kelompok mendapatkan apa yang mereka butuhkan dan inginkan dengan menciptakan, menawarkan, mempertukarkan produk yang bernilai dengan pihak lain. ${ }^{20}$ Anton Ramdan mendefinisikan pemasaran adalah nyawa dari suatu bisnis yang sedang dijalankan. Sederhananya, marketing adalah alat untuk mengenalkan, memasarkan dan menarik konsumen sehingga membeli produk yang ditawarkan. ${ }^{21}$

Hermawan Kertajaya mendefinisikan marketing syariah sebagai strategi bisnis, yang harus memayungi seluruh aktivitas dalam sebuah perusahaan meliputi seluruh proses, menciptakan, menawarkan, pertukaran nilai dari seorang produsen atau satu perusahaan atau perorangan yang sesuai dengan ajaran Islam. ${ }^{22}$ Lebih lanjut Hermawan menguraikan

\footnotetext{
${ }^{19}$ Ibid.93

${ }^{20}$ Kotler and Lane Keller, Manajemen Pemasaran, Ed. 12 Jilid. 1 (Indonesia: PT. Macanan Jaya Cemerlang, 2006). 6

${ }^{21}$ Anton Ramdan, Etika Bisnis Dalam Islam (Jakarta: Bee Media Indonesia, 2013). 78

${ }^{22}$ Hermawan Kertajaya and Muhammad Syakir Sula, Marketing Syariah (Bandung: Mizan, 2008).260
} 
karakteristik dari syariah marketing ini terdiriatas beberapa unsur yaitu:

1. Theistis (Rabbaniyah),

2. Etis (Akhlāk),

3. Realistik (Al-Waqiyah),

4. Humanistis (Al- Insaniyah)

Jika kita tinjau keempat elemen di atas, pertama, berdasarkan Ketuhanan, yaitu satu keyakinan yang bulat, bahwa semua gerak-gerik manusia selalu berada di bawah pengawasan Ilahi yang Maha Kuasa, Maha Pencipta, Maha Pengawas. Oleh sebab itu, semua insan harus berperilaku sebaik mungkin, tidak berperilaku licik, suka menipu, mencuri milik orang lain suka makan harta orang lain dengan jalan yang bathil. Nilai Rabbaniyah ini melekat atau menjadi darah daging dalam pribadi setiap muslim, sehingga dapat mencegah perbuatan tidak terpuji dalam konteks bisnis.

Kedua, etis, artinya, semua perilaku berjalan diatas norma etika yang berlaku umum. Etika adalah kata hati, dan kata hati ini adalah kata yang sebenarnya, tidak bisa dibohongi.Oleh sebab itu, hal ini menjadi panduan para marketer syariah agar selalu memelihara setiap tutur kata, perilaku dalam berhubungan bisnis dengan siapa saja, baik konsumen, penyalur, toko, pemasok ataupun saingannya.

Ketiga, realistis, artinya, sesuai dengan kenyataan, jangan mengada-ada apalagi yang menjurus kepada kebohongan.Semua transaksi yang dilakukan harus berlandaskan pada realita, tidak membeda-bedakan orang, suku dan warna kulit, semua tindakan penuh dengan kejujuran.

Keempat, humanistis, artinya berperikemanusiaan, hormat-menghormati sesama, marketing berusaha membuat kehidupan menjadi lebih baik.Jangan sampai kegiatanmarketing malah sebaliknya merusak tatanan hidup di 
masyarakat. ${ }^{23}$ Menurut Kotler, jasa adalah setiap tindakan atau kegiatan yang dapat ditawarkan oleh satu pihak kepada pihak lain yang pada dasarnya tidak berwujud dan tidak mengakibatkankepemilikan apapun. Jasa juga merupakan aktivitas, manfaat atau kepuasan yang ditawarkan untuk dijual. Berdasarkan pendapat-pendapat tersebut dapat disimpulkan bahwa jasa adalah setiap kegiatan, manfaat atau kepuasan yang ditawarkan oleh satu pihak kepada pihak lain dan tidak berakibat pemindahan hak milik benda.

\section{Kaffahisme Ekonomi}

Kaffahisme ekonomi merupakan teori atau konsep terapan yang dimaksudkan untuk pelaku ekonomi serta bisnis dalam pengupayaannya terhadap masifnya perekonomian berbasis syariah. Kaffahisme berasal dari dua unsur kata yaitu kaffah (ka-fah) yang berarti kompleks atau menyeluruh (masif) dan isme yang artinya paham atau orientasi. Sehingga jika diartikan maksud dari kaffahisme adalah suatu sistem ekonomi beborientasi menyeluruh yang bersandarkan pada referensi AlQuran dan Hadis atau berasaskan Islam. ${ }^{24}$

Kaffahisme lebih mengarah kepada bagaimana sebuah orientasi yang dilakukan oleh seseorang dapat memberikan dampak efektif dan positif secara massif. Kaffahisme juga merupakan temuan pendekatan dalam sistem perekonomian yang berhasil membawa perubahan besar secara global. Pertama, untuk kesalehan individual dan kesalehan sosial bagi umat Islam. Kedua, dapat memenangkan persaingan harga yang ditawarkan dengan kapitalis. Ketiga, mendapatkan feedback positif berupa keuntungan dunia dan akhirat sekaligus. ${ }^{25}$

\footnotetext{
${ }^{23}$ Alma Bukhori and Donni Juni Priansa, Manajemen Bisnis Syariah (Bandung: Alfabeta, 2009).258-259

${ }^{24}$ Zulfikar MS, Kaffahisme Ideologi Ekonomi Masa Depan (Jakarta: Elex Media Komputindo, 2014).40

${ }^{25}$ Ibid.40
} 
Selain itu, kaffahisme merupakan sistem ekonomi yang melibatkan partisipasi umat (menyeluruh), membawa dampak baik terhadap lingkungan mikro maupun makro serta menyadarkan bahwa keuntungan di dunia berasal dari besar atau kecilnya rejeki yang diturunkan oleh Allah Swt., kepada manusia. ${ }^{26} \mathrm{Hal}$ tersebut sesuai dengan konsep Islam jika disimak lebih mendalam. Dalam Al-Quran Surat Al-Baqarah Ayat 208 yang artinya: "Wahai orang-orang yang beriman, masuklah kalian dalam Islam secara keseluruhan dan janganlan kamu ikuti langkah-langkah setan. Sesungguhnya setan itu musuh yang nyata bagimu." (QS. Al-Baqarah: 208).

Toto Tasmara menjelaskan, kaffah merupakan keadaan yang menyeluruh dan kaffahisme adalah paham tentang bagaimana manusia dapat memahami dan berlaku secara keseluruhan serta tidak setengah-setengah. Artinya, seluruh jiwa dan raganya dipenuhi dengan kesadaran untuk berpihak hanya kepada Allah dan Rasul-Nya. Dalam pengibaratan yang ditulis, kaffah bagaikan seorang yang terjun ke laut, seluruh tubuhnya mulai dari ujung rambut sampai kaki basah dan asin. $^{27}$

Nayih Azubi, pemikir asal Mesir, dalam bukunya Hamid Basyaib menyatakan bahwasanya kaffahisme merupakan pandangan pemahaman yang melihat sesuatu sebagai totalitas sistem. Seperti halnya Islam yang meliputi "tiga d", yakni al-din (agama), al-dunya (dunia) dan al-daulah (negara). Dalam pandangan ini, Islam mengatur semua hal, mulai dari urusan negara, politik, ekonomi sampai urusan masuk WC dan kamar tidur. $^{28}$

Dalam Kamus Besar Bahasa Indonesia, kaffah (kafah /ka-fah/) berarti sempurna atau keseluruhan, seperti dalam kalimat "Kerinduan untuk menempatkan diri sebagai seorang

\footnotetext{
${ }^{26}$ Ibid. 44

27 Toto Tasmara, Menuju Muslim Kafah (Jakarta: Gema Insani Press, 2000).49

${ }^{28}$ Hamid Basyaib, Membela Kebebasan: Percakapan Tentang Demokrasi

Liberal (Bandung: Alvabet, 2006).234
} 
muslim yang kafah". ${ }^{29}$ Dengan kata lain tidak ada satupun yang tertutupi atau dalam kondisi setengah-setengah. Kaffah (kafah /ka-fah/) berarti pula memasukkan seluruh relung kehidupan atas dasar keyakinan bahwa dirinya hanya pantas menjadi hamba Allah yang Maha Pengasih. ${ }^{30}$

Ekonomi merupakan ilmu mengenai asas-asas produksi, distribusi, dan pemakaian barang-barang serta kekayaan (seperti hal keuangan, perindustrian, dan perdagangan); pemanfaatan uang, tenaga, waktu, dan sebagainya yang berharga; tata kehidupan perekonomian (suatu negara); urusan keuangan rumah tangga (organisasi dan negara). ${ }^{31}$

Sedangkan menurut Adam Smith Ekonomi ialah penyelidikan tentang keadaan dan sebab adanya kekayaan negara. Di sisi lain, Hermawan Kertajaya memberikan definisi ekonomi sebagai platform dimana sektor industri melekat diatasnya. Menurut Abraham Maslow, ekonomi merupakan salah satu bidang pengkajian yang mencoba menyelesaikan masalah keperluan asas kehidupan manusia melalui penggemblengan segala sumber ekonomi yang ada dengan berasaskan prinsip serta teori tertentu dalam suatu sistem ekonomi yang dianggap efektif dan efisien.

\section{Teknis Implementasi Kaffahisme Pada Sektor Pemasaran Modern (Dropship)}

Era milenial yang semakin marak dengan keberwujudan dunia digital, di mana manusia harus lebih baik lagi dalam mengatur segala aspek kehidupan. Tidak berbeda dengan implementasi pada sektor pemasaran modern (dropship) secara kaffah atau menyeluruh. Dalam penerapan ekonomi kaffahisme, setidaknya ada tiga faktor penting yang harus diketahui dan mendapat perhatian khusus. Ketiga jenis faktor tersebut dapat diuraikan sebagai berikut:

\section{Sektor Finansial}

29 " http://www.kbbi.web.id/kafah.

30 Tasmara, Menuju Muslim Kafah.50

31 "Http://Www.Kbbi.Web.Id/Ekonomi." 
Pada dasarnya setiap operasional dunia bisnis yang sedang dilakukan tidak akan lekang dari unsur financial atau modal. Dalam aktivitas pemasaran modern juga membutuhkan sarana financial untuk keberlangsungan operasional dengan baik dan lancar. Hanya saja perbedaan mendasar berada pada efisien dan efektivitas pemasaran yang dilakukan.

Dalam dunia pemasaran modern (dalam hal ini adalah dropship) tidak membutuhkan biaya operasional yang besar dan membengkaknya biaya seperti di era klasik. Dalam menjalankan aktivitas tersebut yang dibutuhkan adalah perizinan legal (lisan atau tulisan) dari pemilik barang/jasa, spesifikasi barang yang akan dijual serta detail gambar, rincian harga dan kesepakatan keuntungan yang akan diperoleh oleh tenaga pemasar modern (dropshipper).

2. Sektor Bisnis atau Perniagaan

Setelah memahami betul tentan sektor utama (finansial) maka hal urgen berikutnya adalah sektor bisnis (perdagangan atau perniagaan). Di mana sektor ini merupakan sektor lanjutan dari ketersediaan financial yang kemudian para pelaku bisnis dapat memilih dan memilah perniagaan bidang apa saja yang dapat dijalankan dengan baik, masif, bermanfaat dan melahirkan kemaslahatan publik. Hal ini sangat penting untuk ditelaah dan dianalisa kembali, mengingat banyaknya pelaku bisnis yang baik dalam hal financial tetapi gagal pada penentuan sektor perniagaan yang sedang dijalankan. Hasilnya pelaku bisnis yang demikian hanya akan memperoleh pengalaman dan minimnya modal utama.

3. Sektor Pasar atau Lapangan

Sektor ini merupakan sekelompok orang yang memiliki kebutuhan, keinginan dan kemampuan untuk keberlangsungan aktivitas jual beli. Menurut William J. Stanton pasar merupakan sekumpulan orang yang memiliki keinginan untuk puas, uang yang digunakan untuk belanja, serta memiliki kemauan untuk membelanjakan uang 
tersebut. ${ }^{32}$ Pendapat lain muncul dari Kotler dan Amstrong, pasar adalah seperangkat pembeli aktual dan juga potensial dari suatu produk atau jasa. Ukuran dari pasar itu sendiri tergantung dengan jumlah orang yang menunjukkan tentang kebutuhan dan memiliki kemampuan dalam bertransaksi. 33

\section{Implementasi Dropship dalam Ruang Lingkup Pemberdayaan kaffahisme ekonomi oleh CV. Karya Utama Surabaya}

Dari setiap operasional terkait implementasi model pemasaran modern (dropship) dalam ruang lingkup pemberdayaan yang masif, standar operasional harus tetap menjadi prioritas utama untuk keabsahan aktivitas dan sebagai pegangan prinsip. Berikut adalah penerapan aktivitas atau kegiatan pemasaran modern (dropship) yang dilakukan di dalam Karya Utama Surabaya.

Pelaku dropship (dropshipper) memilih atau menentukan distributor terlebih dahulu. Kemudian mengambil keputusan untuk melakukan kontrak perizinan baik lisan ataupun tulisan (antara pemilik barang dengan dropshipper) dalam hal ini adalah CV. Karya Utama Surabaya dengan pelaku dropship. Setelah adanya perizinan baik lisan ataupun tulisan (kontrak), maka secara langsung pelaku dropship ini menjadi mitra dari Karya Utama Surabaya. Kemudian penentuan atas kesepakatan perihal penjualan, spesifikasi produk, harga dan keuntungan yang didapatkan.

Jika di kemudian hari terdapat konsumen atau pembeli yang berkeinginan untuk membeli barang atau produk dari Karya Utama Surabaya (melalui dropshipper) maka pembeli diperkenankan untuk melakukan pembayaran terlebih dahulu. Setelah hal tersebut dilakukan, maka dropshipper memberikan informasi kepada distributor atau pemilik barang untuk

\footnotetext{
32 William J and Stanton, Prinsip Pemasaran Jilid 1 (Jakarta: Erlangga, 2009). 78

${ }_{33}$ Philip Kotler and Amsrong, Dasar-Dasar Pemasaran (Jakarta: PT. Indeks Kelompok Gramedia, 2004). 139
} 
mengirimkan produk pesanan dari pembeli. Artinya, pemilik barang (CV. Karya Utama Surabaya) akan mengirimkan barang pesanan kepada pembeli dengan mencantumkan nama dari dropshipper yang bersangkutan sebagai identitas pengirimnya. Untuk lebih detailnya, lihat gambar di bawah ini.

\section{Analisis Dropship Dalam Pemberdayaan Kaffahisme Ekonomi}

Aktivitas dropship yang diterapkan oleh CV. Karya Utama Surabaya dan dropshipper memiliki implikasi yang signifikan. Dalam perjalanan praktiknya, konsep dropship atau pemasaran terhadap barang tanpa adanya status kepemilikan banyak memberikan manfaat kepada siapapun (dropshipper) yang berkenan menjalin kemitraan dengan perusahaan.

Dari sumber data jumlah dropshipper CV. Karya Utama Surabaya secara masif, maka langkah pertama dalam melakukan sebuah analisis terhadap data yang ada adalah dengan menghitung prosentase jumlah terperinci responden atas implementasi dropship yang berlaku di Karya Utama Surabaya terhadap pemberdayaan ekonomi secara kaffah.

Dalam wawancara yang sedang berlangsung, ketika bersinggungan terkait konsep dropship dan ekonomi kaffah (kaffahisme ekonomi), Arif Budiansyah selaku komisaris perusahaan mengatakan; "Dropship itu kan konsep terapan mas. Bisa dilakukan sama perusahaan manapun. Jangankan perusahaan yang besar, usaha mikro yang memiliki produk tanpa embel-embel perusahaan (cukup home industry) sangat bisa mengaplikasikannya. Tapi mas, yang perlu diketahui lagi, di dalam bisnis itu bukan kanya untuk kebutuhan perut saja. Di samping closing penjualan barang atau jasa, ada hal penting yang perlu diperhatikan, ya seperti memberlakukan ekonomi secara kaffah. Bingung ya? Maksudnya itu ya bisnisnya lempeng, sesuai standar hukum negara dan tidak nyalahi 
agama, siapapun bisa bergabung jadi mitra (dari anak-anak sampai yang tua)." 34

Dari data yang penulis dapatkan total responden selama delapan kali wawancara adalah 47 dropshipper dengan masingmasing profesi yang berbeda. Jika dihitung dan dikalkulasi dengan hitungan persen maka ditemui lebih dari $50 \%$ dropshipper secara masif merasakan ada dampak positif dari aktivitas kemitraan berupa dropship yang sedang dijalani dengan Karya Utama Surabaya.

Penulis menilai implementasi dropship yang diberlakukan Karya Utama Surabaya cukup berpengaruh terhadap ekonomi secara kaffah. Ada beberapa lini profesi berbeda yang masih tetap bergabung sebagai tenaga pemasar modern dengan sistem dropship atau dropshipping meskipun hasilnya tidak terlalu besar. Kemudian penulis hanya menemukan satu titik pada profesi pelajar kurang dari 17 tahun yang mengatakan feedback terhadap mereka atas sebuah aktivitas dropshipping hanya menduduki 40\%. Lain daripada itu angka persen menunjukkan lebih dari 50\% yang merasa dibantu secara masif (mulai dari pemanfaatan waktu luang, pemanfaatan gadget, penambahan penghasilan dan lain sebagainya). Berikut hasil wawancara dengan M. Riswan Effendi;

"Banyak pelaku dropship di perusahaan mini kami yang bervariasi profesinya, mas. Mulai dari anak-anak yang belum genap usia 17 tahun hingga ibu rumah tangga. Kami tidak melarang siapapun untuk bergabung. Semua kalangan, usia, profesi bisa menjadi mitra. Toh ini bukan $M-L-M$ kan mas, yang dapat menguntungkan dan merugikan salah satu pihak. Nah jika berbicara omzet, sebenarnya tidak sedikit yang dihasilkan secara komulatif. Artinya, dropshipper banyak menunjang penjualan perusahaan dengan bermodal gambar dan spesifikasi detail dari perusahaan kami. Jika dikalkulasi

\footnotetext{
${ }^{34}$ M. Arif Budiansyah, Komisaris, Wawancara, Surabaya, 15 Maret 2018.
} 
total, keseluruhan dropshipper (yang jumlahnya lebih dari 50 orang) bisa menghasilkan paling tidak 200-300 transaksi penjualan dalam satu bulan. Kira-kira tembus omzet 15-30 juta setiap pekannya. Tergantung jenis buku yang terjual dan musim-musim tertentu juga. Kalau musimnya anak masuk sekolah dan kuliah seperti tahun ajaran baru, omzet dari dropshipper saja bisa mencapai 500 juta per bulan. Satu lagi, jika disinggung terkait sebuah pemberdayaan, kami memang memberdayakan. Mulai dari kecanggihan teknologi, modernisasi zaman, bentuk kemitraan, model penjualan dan lain sebagainya. Kemudian jika ditanya, apakah mereka merasa ada sebuah pemberdayaan yang berefek pada ekonomi secara masif? Maka jawabannya ada pada pribadi para pelaku". ${ }^{35}$

Jumlah dropshipper yang bergabung setiap bulannya selalu bertambah, akan tetapi lebih ke arah mencoba dan pergi. Akan tetapi tingkat konsumen atau pembeli selalu mengalami perubahan, baik identitas pembeli maupun wilayah. Hal ini tentu karena faktor pemasaran yang dilakukan oleh tenaga pemasar seperti dropshipper. Bagi penulis, ini adalah kejadian yang tidak aneh mengingat pelaku dropship yang memasarkan barang dengan detail, pelayanan baik, komunikasi lancar, tanggung jawab penuh dan lain sebagainya.

Jika dianalisa kembali, semakin banyak yang bergabung dan menjadi mitra sebagai dropshipper pada CV. Karya Utama Surabaya maka akan semakin besar peluang untuk terjualnya produk dan melebarnya sayap informasi terkait perusahaan. Dengan semakin gencarnya dropshipper memasarkan barang, maka semakin besar pula peluang konsumen membeli produk yang ditawarkan. Dengan demikian akan muncul feedback positif yang akan kembali pada dropshipper dan terwujudnya kaffahisme ekonomi (konsep terapan ekonomi yang melibatkan

35 M. Riswan Effendi, Manajer Marketing, Wawancara, Surabaya, 15 Maret 2018 . 
pasrtisipasi umat serta mengoperasikan totalitas sistem dengan berlandaskan syariah).

Penulis telah menganalisa beberapa data melalui media teori yang dicanangkan pada bab sebelumnya, mulai dari pemasaran modern, sistem dropship atau dropshipping berbagai perspektif, pelayanan, fasilitas yang memadai, loyalitas dari pelaku dropship serta customer dan pemberdayaan konsep dropship yang mengarah pada sebuah pemberdayaan ekonomi skala masif. Dari sini, tidak bisa dipungkiri bahwa kegiatan jual beli yang dikemas rapi dalam sebuah bentuk dropship sangat berpengaruh pada sebuah pemberdayaan ekonomi yang kaffah (profesi, usia, nilai dan lain sebagainya).

Transaksi dropshipping merupakan salah satu metode jual beli secara online, di mana badan usaha atau perorangan baik itu toko online atau pengecer (dropship) tidak melakukan penyetokkan barang, dan barang didapat dari jalinan kerja sama dengan perusahaan lain yang memiliki barang yang sesungguhnya atau yang disebut dropshipper. Secara istilah dropshipping adalah metode jual beli secara online, dropship adalah istilah bagi toko online, dan dropshipper adalah pelaku dropship.

Dengan menjaga kepercayaan kepada pembeli merupakan cara terbaik untuk mempertahankan bisnis online terus berkembang. Bukan tidak mungkin apabila pembeli merasa tertipu dengan barang yang dibeli maka akan berdampak pada perkembangan bisnis dhropsip tersebut. Hal ini juga seharusnya sudah barang tentu menjadi perhatian serius bagi pelaku bisnis dropship terutama bagi supplier untuk memantau dropshippernya karena dikhawatirkan terjadi kecurangan harga atau pemanfaatan situasi penentuan harga, yang bisa berdapak pada kerugian terhadap supplier.

Perilaku konsumtif merupakan tindakan seorang membeli suatu barang tanpa adanya pertimbangan yang masuk akal dimana seorang tersebut dalam membeli suatu barang tidak didasarkan pada faktor kebutuhan. Perkembangan Online 
shop atau belanja online di Indonesia berkembang dengan pesat dan cepat. Padahal beberapa tahun silam, trend Online Shop di Indonesia masih belum populer karena kebiasaan masyarakat Indonesia yang cenderung memiliki anggapan "ada uang - ada barang", layaknya berbelanja di swalayan atau di pasar tradisional. Kondisi jaringan internet yang kurang cepat juga merupakan salah satu kendala bagi sistem Online Shop di Indonesia. Kini Indonesia adalah salah satu negara yang trend dengan toko online atau online shop, hal ini dapat dilihat mulai bermunculan banyaknya toko online atau online shopping seperti Kaskus.co.id, olx.com, bukalapak.com, Laku.com dan masih banyak lagi, yang bisa ditemukan dengan mudah sesuai kategori barang dagangan yang akan dicari ataudibeli.

Saat ini tata cara penggunaan belanja online dapat dilakukan dengan sangat mudah. Ketika pembeli tertarik dengan barang yang dijual oleh orang lain, pembeli cukup melakukan panggilan telepon kepada penjual, mengetikkan sms atau whatsapp sesuai aturan. Setelah pesan diterima, pembeli biasanya diharuskan mentransfer sejumlah uang ke rekening penjual dan barang yang dibeli pun akan dikirim baik melalui kurir (jika wilayah pengiriman masih cukup dekat) ataupun melalui jasa POS, JNE, J\&T, Travel dan lain-lain. Hal ini sesuai dengan uraian dalam wawancara bersama Hengki Hendra P. Berikut ;

"Perusahaan kita menerapkan konsep dropship untuk menunjang penjualan produk mas. Di sisi lain, perusahaan ini kan juga pengen berbagi dengan yang lainnya. Salah satunya ya dengan menjalin kemitraan, di mana hubungan ini kemudian bisa menjadi saling menguntungkan (simbiosis mutualisme). Terkait bagaimana dropshipper mendapatkan gambar produk, spesifikasi dan harganya, biasanya lewat grup WhatsApp dan aplikasi lain yang menunjang. Di sana kami paparkan dan share semuanya. Mulai dari gambar 
Dropshipping Pada CV. Karya Utama Surabaya Terhadap Pemberdayaan...

produk (buku), spesifikasi (judul, penulis, tebal halaman, tahun terbit) dan kemudian harga."36

Dalam penuturan lebih lanjut yang disampaikan oleh PJ. Store Online, setiap dropshipper wajib mencantumkan ekspedisi dan atau kurir yang dipilih pembeli. Hal ini dilakukan karena untuk menghindari sesuatu yang tidak diinginkan terjadi, seperti anggaran ongkos kirim yang membengkak, estimasi sampainya paket tidak sesuai, unit ekspedisi jauh dari kediaman pembeli (akses kurang lancar) dan lain sebagainya.

Untuk toko online tertentu pembayaran dapat dilakukan baik menggunakan kartu debit, kartu kredit, PayPal, memotong pulsa pelanggan (untuk transaksi lewat HP), cek, maupun COD (Cash On Delivery) yaitu pembayaran yang dilakukan ketika barang telah dikirim oleh penjual. Cash On Delivery biasanya dilakukan melalui tatap muka antara penjual dan pembeli, penjual dapat menunjukkan barangnya sehingga pembeli yang tertarik bisa meneliti barang yang akan ia beli. Pembelian semacam ini biasanya melakukan pembayaran secara langsung/uang kontan. Selain tatap langsung antara penjual dan pembeli, COD ini bisa dilakukan antara kurir dan pembeli; biasanya penjual hanya akan melayani COD apabila daerah pembeli masih dapat dijangkau oleh penjual.

Menurut penulis, pihak penjual harus memelihara kepuasan pelanggan agar dapat mempertahankan loyalitan dan hubungan jangka panjang dengan para pembelinya. Agar dapat bertahan hidup didalam era online shopping, pihak penjual harus memiliki pelanggan yang loyal (customer loyality) yang percaya terhadap keunggulan dari jasa online shopping.

Pertumbuhan pasar online di dunia dan juga dirasakan oleh negeri ini dan juga di kalangan mahasiswa bahkan terus meningkat setiap tahunnya. Hal ini membuka celah peluang bisnis sekaligus menghadirkan tantangan. Bagi seorang pebisnis, harus bisa mengembangkan online shop dengan

\footnotetext{
${ }^{36}$ Hengki Hendra P, PJ. Store Online, wawancara, Surabaya, 15 Maret 2018.
} 
memaksimalkan berbagai metode kreatif. Ketatnya persaingan di bisnis online menuntut para pebisnis untuk bisa meningkatkan kemampuannya dalam mengelola onlineshop.

Tidak bisa dipungkiri lagi bahwasanya faktor trust oleh konsumen terhadap market online dewasa ini tetap menjadi persoalan utama bagi pebisnis modern. Kepercayaan pasar Indonesia terhadap online shop masih tergolong rendah. Salah satunya diperngaruhi maraknya penipuan yang dilakukan oknum tidak bertanggung jawab. Padahal jika dianalisa ulang, kepercayaan konsumen akan merambak pada kepuasan dan berimplikasi pada sebuah loyalitas yang tinggi.

Hal ini menjadi tantangan bagi para pebisnis online di Indonesia. Harus ditemukan metode kreatif atau teknik unik untuk mengatasi permasalahan ini. Beberapa cara yang patut untuk dicoba adalah dengan mengoptimalkan manfaat dari testimoni.

Kepercayaan bisa muncul dari kepuasan konsumen terhadap produk dan pelayanan. Salah satu kendala dari bisnis online adalah pembeli tidak bisa bertemu langsung dengan penjual dan tidak bisa melihat produk real-nya. Pebisnis online harus meyakinkan calon konsumen bahwa online shopnya telah dipercaya oleh banyak pelanggan sehingga bebas unsur penipuan. Calon pembeli biasanya mempertimbangkan testimoni dari orang-orang yang sudah membeli produk dari suatu online shop. Hal ini menjadi alasan pentingnya testimoni produk bisnis online untuk mendapatkan dan meningkatkan kepercayaan konsumen terhadap online shop.

Testimoni merupakan pernyataan kesaksian atau respon konsumen terhadap produk, jasa atau pelayanan yang disampaikan secara lisan dan tulisan kepada penjual. Responnya bisa berupa komentar, kritik, saran, opini, ungkapan rasa terima kasih dan rasa puas atau kecewa. Testimoni kuat dan berkualitas bisa semakin mempermudah pebisnis online dalam mendapatkan kepercayaan dari calon konsumen. Terutama untuk bisnis online yang baru berjalan, 
Dropshipping Pada CV. Karya Utama Surabaya Terhadap Pemberdayaan...

testimoni terbukti ampuh untuk membangun kepercayaankonsumen.

Dalam siklus yang panjang dan ditarik dari benang agama, Islam memiliki aturan yang jelas terkait perihal transaksi jual beli sebagai landasan bisnis bagi umat Islam.Pada prinsipnya, setiap pelaku transaksi di dalam dunnia jual beli harus mengerti attitude yang berlaku. Hal ini diperlukan untuk menghindari kezaliman, maysir, gharar, riba dan tadlis.

Etika merupakan sebuah standarisasi perilaku bermoral yang diterima oleh keumuman masyarakat sebagai bernar versus salah. ${ }^{37}$ Etika juga tidak pernah lepas dari aktivitas kehidupan manusia di dunia termasuk kegiatan jual beli. Adapun beberapa alasan etika tidak bisa terlepas dari aktivitas manusia dalam hal bisnis adalah sebagai berikut:

Pertama, keumuman masyarakat pada dasarnya dibentuk atas dasar aturan dan etika. ${ }^{38}$ Norma-norma, nilai agama dan budaya menjadi nafas etika yang harus dipatuhi para pelaku bisnis untuk bertahan dan berkembangnya sebuah perusahaan (bisnis) tersebut. Eksistensi etika merupakan sebuah lampu aturan yang dapat menjadi acuan standar dalam melakukan kinerja masif. ${ }^{39}$ Walaupun bisnis online tergolong lintas budaya, agama dan negara misalnya, tetap harus memperlihatkan norma, nilai dan budaya untuk kebaikan bersama.

Kedua, bisnis merupakan instrumen kekuatan yang memiliki pengaruh besar terhadap kehidupan manusia dan sebanding dengan kekuatan agama serta politik. ${ }^{40}$ Artinya tanpa adanya keraguan, eksistensi etika dalam berbisnis sangat

\footnotetext{
${ }^{37}$ William G Nickles and Dkk, Pengantar Bisnis Edisi Delapan Buku Dua (Terj.) (Jakarta: Salemba Empat, 2010).117

${ }^{38}$ Iwan Triwuyono, Perspektif, Metodologi Dan Teori Akuntansi Islam (Jakarta: Rajawali Perss, 2006).73

39 Ahmad Syaifuddin, Jual Beli Dropship Dalam Perspektif Etika Bisnis Islam

(Semarang: UIN Walisongo, 2017).96

${ }^{40}$ Triwuyono, Perspektif, Metodologi Dan Teori Akuntansi Islam.7
} 
erat kaitannya dengan perjalanan aktivitas manusia ketika bertraksaksi jual beli.

Ketiga, manusia sebagai ciptaan Allah Swt., yang dijadikan khalifah di muka bumi ini, seyogyanya menjalankan tugasnya dengan baik dan memiliki kapasitas sebagai individu yang mampu bersaing dan menciptakan kondisi jaringan bisnis yang kuat.

\section{Analisis Dropship Dalam Perspektif Islam}

Muncul dan berkembangnya disruptif teknologi di era milenial ini mengundang banyak pelaku usaha yang lebih cermat melihat dan memanfaatkan peluang yang ada. Dalam hal ini, CV. Karya Utama Surabaya merupakan salah satu contoh kecil dari sekian banyaknya perusahaan nasional yang memberdayakan eksistensi modernitas zaman.

Arif Budiansyah sebagai komisaris memberikan arahan penting berupa pemanfaatan dunia digital dengan tanpa melupakan keberadaan mitra. Dengan bertambahnya mitra dan partner perusahaan akan semakin kuat, pemasaran meluas, hasil penjualan meningkat, perusahaan banyak dikenal masyarakat umum tidak lain karena berlakunya pemasaran modern yang dilakukan oleh dropshipper dengan sistem dropship. ${ }^{41}$

Bagi setiap perusahaan yang berkembangnya mengikuti zaman seperti Karya Utama Surabaya, menjaga sistem penjualan offline dan memberlakukan sistem penjualan modern (dropship) tidak asing lagi didengar. Penulis menyakini di luar sana banyak perusahaan atau usaha mikro kecil menengah juga telah banyak meramaikan sistem pejualan online untuk menunjang kemajuan dan eksistensi bisnis yang dijalankan. Oleh karenanya, permasalahan lanjutan yang sekarang dihadapi adalah bagaimana implementasi yang dilakukan perusahaan, khususnya Karya Utama Surabaya

${ }^{41}$ Arif Budiansyah, Komisaris Karya Utama Surabaya, wawancara, Surabaya, 15 Maret 2015.

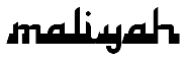


dalam menjalankan aktivitas dan rutinitas perusahaan yang berdampak sebuah pemberdayaan masif.

Dropship merupakan sebuah aktivitas penengah yang berfungsi sebagai penghubung, perantara, wasilah dan jembatan dalam jual beli (antara penjual dan pembeli) dengan keuntungan yang telah disepakati bersama. Sebagai salah satu perusahaan penerbitan dan pendistribusian buku skala nasional, sudah seyogyanya Karya Utama Surabaya menerapkan sistem dropship dalam menunjang omzet perusahaan dan memberdayakan tenaga baru sebagai mitra penjualan sistem modern secara kaffah (profesi, usia, jenis kelamin, ras dan lain sebagainya). Hal ini sesuai dengan fokus penelitian penulis yang mengerucutkan pembahasan masalah tentang dropship perspektif Islam dan implikasi terhadap pemberdayaan kaffahisme ekonomi.

Pada titik garis besarnya, Allah Swt menghalalkan jual beli dan mengharamkan riba. ${ }^{42}$ Artinya segala bentuk jual beli sebenarnya diperbolehkan kecuali ada hal-hal yang menjadikannya haram. Hengki Hendra mengatakan, setiap perjalanan bisnis perusahaan Karya Utama Surabaya tidak ada yang melanggar kode etik berniaga. Semua dilakukan dengan baik dan tidak melanggar hukum di dalam negara Indonesia. ${ }^{43}$ Alhasil, setiap perjalanan bisnis yang tidak melanggar ketentuan (baik negara maupun agama) akan dapat bertahan dan berkembang dengan mengikuti perkembangan peradaban dunia.

Dropship atau dropshipping dikatakan baik dan sesuai standar jual beli berbasis Islam jika tidak menyalahi aturan syariah dan sesuai dengan etika bisnis. Etika merupakan standar perilaku bermoral yang diterima oleh masyarakat secara umum sebagai benar versus salah. Di sisi lain, aktivitas

\footnotetext{
${ }^{42}$ Almizan, Al-Qur'an Disertai Terjemahan \& Transliterasi (Bandung: PT.

Mizan Pustaka, 2007). 72

${ }^{43}$ Hengki Hendra P, Manajer Store Online, wawancara, Surabaya, 15 Maret 2018.
} 
dropship tetap dianggap sah bila sesuai dengan ketentuan ekonomi syariah. Ekonomi syariah merupakan bagian dari bentuk usaha duniawi yang bernilai ibadah juga termasuk suatu amanah, yaitu amanah dalam melaksanakan kewajiban kepada Allah Swt dan kewajiban kepada sesama manusia. ${ }^{4}$

Dalam sebuah kaidah fikih disebutkan "Hukum asal menetapkan syarat dalam muamalah adalah halal dan diperbolehkan kecuali ada dalil yang melarangnya." Artinya, hukum asal syarat sah jual beli merupakan tauqifi, memerlukan dalil. Seseorang tidak boleh menetapkan sesuatu sebagai syarat sah kecuali jika ada dalil sahih yang menunjukkannya. Adapun syarat dalam jual beli maka hkum asalnya halal dan diperbolehkan. Artinya seseorang tidak boleh melarang suatu persyaratan yang dikehendaki pelaku akad muamalah tanpa ada dalil yang melarangnya. ${ }^{45}$ Seperti halnya sebuah konsep modern yang saat ini kita kenal dengan Dropship atau Dropshipping.

Imam Al-Nawawi berkata, apabila dua orang saling memanggil dari jarak jauh kemudian melakukan transaksi jual beli maka hukumnya sah tanpa adanya perselisihan ulama sedikitpun. Dengan jelas memberikan arti, bahwasanya persepektif dan jumhur ulama mengatakan transaksi jual beli konsep dropship, online ataupun dengan wadah yang disebut internet (e-Commerse) adalah boleh berdasarkan metode maslahah al-mursalah atau masalih al-mursalah, ialah cara menemukan hukum sesuatu dengan hal yang tidak terdapat ketentuannya baik dalam al-Qur'an maupun di dalam kitab alhadis, berdasarkan pertimbangan kemaslahatan masyarakat atau kepentingan umum. ${ }^{46}$

\section{Penutup}

\footnotetext{
${ }^{44}$ Abdul Aziz, Ekonomi Islam Analisis Mikro Dan Makro (Yogyakarta: Graha Ilmu, 2008).

${ }^{45}$ Syaikh Muhammad bin Shalihal-Utsaimin, Mudzakkirah Al-Fiqh, Cet. I (Kairo: Dar al-Ghad al-Jadid, 2007).185

${ }^{46}$ Ibid. 10
} 
Berdasarkan dari uraian diatas maka dapat disimpulkan bahwa dalam implementasi aktivitas jual beli dengan sistem dropship di Karya Utama Surabaya telah berjalan dengan baik dan tidak menyalahi aturan berniaga pada umumnya. Memang tidak secara langsung menyebutkan bahwa kegiatan jual beli dengan sistem ini berstandar syariah, akan tetapi semua konsep yang dijalankan mengarah bahkan mengaplikasikan konsep-konsep Islam dalam bermuamalah. Hal ini bisa dilihat dari penerapan yang matang yaitu: (1) Dropshipper atau pelaku dropship dibekali dengan gambar dan spesifikasi produk dengan benar; (2) Melayani dengan baik dan tidak membedakan konsumen dengan garis yang berbeda; (3) Menyampaikan dengan detail dan tanpa adanya manipulasi data.

Implementasi dropship pada CV. Karya Utama Surabaya telah dioperasionalkan dengan baik sesuai dengan standar aturan yang berlaku serta tidak menyalahi hukum negara dan agama, walaupun CV. Karya Utama Surabaya tidak menyebukan secara implicit penerapannya berdasarkan kaidah dan ajaran Islam.

\section{Daftar Pustaka}

Almizan. Al-Qur'an Disertai Terjemahan \& Transliterasi. Bandung: PT. Mizan Pustaka, 2007.

Ascarya. Akad Dan Produk Bank Syariah. Jakarta: RajaGrafindo Persada, 2011.

Aziz, Abdul. Ekonomi Islam Analisis Mikro Dan Makro. Yogyakarta: Graha Ilmu, 2008.

Basyaib, Hamid. Membela Kebebasan: Percakapan Tentang Demokrasi Liberal. Bandung: Alvabet, 2006.

Bukhori, Alma, and Donni Juni Priansa. Manajemen Bisnis Syariah. Bandung: Alfabeta, 2009.

Fauzia, Ika Yunia. "Akad Wakalah Dan Samsarah Sebagai Solusi Atas Klaim Keharaman Dropship Dalam Jual Beli Online." Jurnal Islamica Vol. 9, No (n.d.): 323-343. 
Ghazali, Abdul Rahman. Fiqh Muamalat. Jakarta: Kencana, 2010. Hasan, M Ali. Berbagai Macam Transaksi Dalam Islam (Fiqh Muamalat) Ed. 1 Cet. 2. Jakarta: PT Raja Grafindo Persada, 2004.

Iswidharmanjaya, Dery. Dropshipping Cara Mudah Bisnis Online. Jakarta: PT. Elex Media Komputindo, 2012.

J, William, and Stanton. Prinsip Pemasaran Jilid 1. Jakarta: Erlangga, 2009.

Kertajaya, Hermawan, and Muhammad Syakir Sula. Marketing Syariah. Bandung: Mizan, 2008.

Kotler, and Lane Keller. Manajemen Pemasaran, Ed. 12 Jilid. 1. Indonesia: PT. Macanan Jaya Cemerlang, 2006.

Kotler, Philip, and Amsrong. Dasar-Dasar Pemasaran. Jakarta: PT. Indeks Kelompok Gramedia, 2004.

Miskawayh dalam Nasuka. "Etika Pemasaran Berbasis Islam." Mukaddimah No.17 No.1 (2011): 92.

Moleong, Lexy J. Metode Penelitian Kualitatif. Bandung: Remaja Rosdakarya, 1994.

MS, Zulfikar. Kaffahisme Ideologi Ekonomi Masa Depan. Jakarta: Elex Media Komputindo, 2014.

Mujtaba, Saifuddin. Masailul Fiqhiyah. Jombang: Rousyan Fiqr, 2007.

Nickles, William G, and Dkk. Pengantar Bisnis Edisi Delapan Buku Dua (Terj.). Jakarta: Salemba Empat, 2010.

Perusahaan skala nasional yang bergerak di bidang percetakan. Penerbitan Dan Distiburi Buku. Berada Di Jl. Kasuari Blok A012 No. 15 Krembangan Surabaya (60175), n.d.

Putra, Unggul Pambudi. Sukses Jual Beli Online. Jakarta: Elex Media Komputindo, 2014.

Qadhawi, Yusuf. Halal Dan Haram Dalam Islam (Terjemah Mu'alam Hamidy). Surabaya: Bina Ilmu, 1993. 
Dropshipping Pada CV. Karya Utama Surabaya Terhadap Pemberdayaan...

Ramdan, Anton. Etika Bisnis Dalam Islam. Jakarta: Bee Media Indonesia, 2013.

Saeed, Mohammad, and Dll. "International Marketing Ethics an Islamic Perspective." Journal of Bisnis Ethics Vol.32 No. (2001):

Shalihal-Utsaimin, Syaikh Muhammad bin. Mudzakkirah AlFiqh, Cet. I. Kairo: Dar al-Ghad al-Jadid, 2007.

Syaifuddin, Ahmad. Jual Beli Dropship Dalam Perspektif Etika Bisnis Islam. Semarang: UIN Walisongo, 2017.

Syarifudin. Sedarmayanti. Metodologi Penelitian. Bandung: Mandar Maju, 2002.

Tasmara, Toto. Menuju Muslim Kafah. Jakarta: Gema Insani Press, 2000.

Tim Fokusmedia. Kompilasi Hukum Ekonomi Syariah, Edisi 2011. Bandung: Fokusmedia, 2011.

Tim Prima Pena. Kamus Besar Bahasa Indonesia, n.d.

Triwuyono, Iwan. Perspektif, Metodologi Dan Teori Akuntansi Islam. Jakarta: Rajawali Perss, 2006.

Zuhdi, Masjfuk. Masailul Fiqhiyah. Jakarta: Haji Masagung, 1993.

"Http://Www.Kbbi.Web.Id/Ekonomi."

" http://www.kbbi.web.id/kafah.

M. Riswan Effendi, Manajer Marketing, Wawancara, Surabaya, 15 Maret 2018.

Hengki Hendra P, PJ. Store Online, wawancara, Surabaya, 15 Maret 2018

Arif Budiansyah, Komisaris Karya Utama Surabaya, wawancara, Surabaya, 15 Maret 2015

Hengki Hendra P, Manajer Store Online, wawancara, Surabaya, 15 Maret 2018. 